Available online at: http://journal.uinsgd.ac.id/index.php/IJIK

IJIK, Vol. 9 No. 2: 80 -84

\title{
COMMUNICATION STRATEGY OF ISLAMIC EXTENSION IN THE INDONESIAN-MALAYSIA BORDER REGION
}

\author{
Halim Setiawan \\ Pascasarjana UIN Sunan Gunung Djati Bandung \\ Email : setiawanhalim@gmail.com
}

\begin{abstract}
Paloh District has its characteristics or characteristics that are different from other border areas. The culture of the people is different, the level of education is different so that the messages delivered are also different da'wah. The da'wah challenges faced by Non Civil Servant Islamic Religious Instructors are also different. The purpose of this study was to explain the choice of strategy and message design of Non-PNS Islamic Extension Instructors in Paloh District, Sambas Regency. Research is based on a macro cognitive theory with naturalistic and qualitative paradigms. The process of delivering da'wah messages in the guidance and counselling activities of Islam uses the choice of strategy and message design. Submission of da'wah messages carried out in three forms of counselling activities, namely the Al-Quran Education Park (TPQ), Mosque Youth and Taklim Assembly. The choice of a strategy used is by reading, memorizing and lecturing. While the message design used is informative and persuasive with the type of message of faith, worship and morals.
\end{abstract}

Keywords: Communication, Extension, Border

\section{INTRODUCTION}

One area in Indonesia that has borders with other countries is Sambas Regency. Sambas Regency is a district that borders with the State of Malaysia which is precisely bordered with Sarawak (East Malaysia) (Arifin, 2011). Sambas Regency has 19 districts including Selakau, East Selakau, Pemangkat, Semparuk, Salatiga, Tebas, Tekarang, Sambas, Subah, Sebawi, Sajad, Jawai, South Jawai, Keramat Bay, Galing, Tangaran, Sejangkung, Sajingan Besar, and Paloh. Sajingan Besar Subdistrict and Paloh Subdistrict are districts that border directly with neighbouring countries namely Malaysia.

Paloh Subdistrict is one of the two sub-districts that are directly adjacent to the State of Malaysia (Mayona, Salahudin, \& Kusmastuti, 2016). Administratively, Paloh Subdistrict consists of eight villages. The villages in Paloh Subdistrict are Sebubus, Nibung, Malek, Tanah Hitam, Matang Danau, Kalimantan, Temajuk and Mentibar Villages. One of the villages that border directly with the State of Malaysia is Temajuk Village. The centre of Paloh Subdistrict is Liku in Nibung Village. The distance of the sub-district centre to the district is $54 \mathrm{KM}$, while the distance of the sub-district centre to the province is $280 \mathrm{Km}$.

Building Human Resources (HR) in the community of Paloh District cannot be separated from education (Sudarsana, 2016). Be it public education or Islamic education. Islamic religious education is very important to balance out general education and as a bulwark and a guide for daily life. Islamic religious education is obtained not only in schools but outside of school (Suradi, 2017). Religious education outside of school is obtained from people who have high religious knowledge and religious leaders in the District of Paloh. Besides religious education is also obtained from religious activities in the community. But specifically, there are religious educators assigned to guide the community and provide Islamic education to the community, especially the people of the District of Paloh. The Islamic guidance and

* Copyright (c) 2019 Halim Setiawan

This work is licensed under a Creative Commons Attribution-ShareAlike 4.0 International License.

Received: 20 May 2019; Revised: 20 Juny 2019; Accepted: 29 Juny 2019 
counselling are carried out by Islamic Religious Instructors assigned by the District Ministry of Religion to carry out Islamic guidance and counselling in the District of Paloh (Pasmika \& Mauluddin, 2016).

The enactment of Law Number 23 of 2014 concerning Government has provided significant changes to the running of government in the regions where regulations are arranged for state apparatus (Fauzi, 2019). Like the Islamic Religious Instructor who is under the auspices of the Ministry of Religion, Sambas Regency, there are two types, namely Functional Islamic Religious Instructor or Islamic Civil Servants and Non Civil Servant Islamic Religious Instructors. Functional Islamic Extension Officers on duty in Sambas Regency are only three in number. The amount is not proportional to the total area and the number of sub-districts in Sambas Regency. No Functional Islamic Religious Instructor is assigned to foster in the District of Paloh. While the number of Non-Civil Servant Islamic Religious Instructors who passed the selection throughout the Sambas Regency was 136 people and the Islamic Religious Instructors who passed the selection for Paloh District were only 10 people. Paloh Subdistrict is the second widest subdistrict after Sajingan Besar Subdistrict with the number of Non-PNS Islamic Religious Instructors only 10 people, making the Non-PNS Islamic Religious Instructors must prepare themselves as fully as possible in guiding the community.

The role of Non-PNS Islamic Religious Instructors in conducting Islamic guidance and counselling in the District of Paloh is very important. Because Paloh Subdistrict is a sub-district that is in direct contact with the State of Malaysia, so social and cultural contact also occurs in the District of Paloh. Besides that, the people in Paloh Subdistrict are the majority of Muslims. The importance of Islamic Religious Instructors in the District of Paloh is also due to the lack of optimal Islamic education. There are still many people who cannot read the Koran and cannot pray. Therefore it is very necessary for the presence of an Islamic Religious Instructor who can guide the community to be better in worship.

Paloh District has its characteristics or characteristics that are different from other border areas. The culture of the people is different, the level of education is different so that the messages delivered are also different da'wah. The da'wah challenges faced by Non Civil Servant Islamic Religious Instructors are also different. Non-PNS Islamic Religious Instructors have to deal with infrastructure limitations, lack of human resources, and difficult coordination due to a great distance, making many people discouraged to become Non-PNS Islamic Religious Instructors in Paloh District. So that the number of people who registered themselves to participate in the selection to become Non-Civil Servant Islamic Religious Instructors in Paloh District became less (A'ing, 2015).

The shortage of Non-PNS Islamic Religious Instructors in Paloh District has an impact on optimizing the message delivered to the community. Long distances, minimal human resources, difficult coordination and inadequate infrastructure. These factors make the Non Civil Servant Islamic Religious Instructor in Paloh Subdistrict have to find the right strategy so that the preaching messages delivered through Islamic guidance and counselling activities can be received by the community as much as possible. The communication strategy used by Non-Civil Servant Islamic Religious Instructors in Paloh District is different from other regions. Natural conditions, geographical location, and socio-cultural conditions of society will determine a communication strategy that is made.

\section{METHODOLOGY}

meanings adopted by a group of humans can only be understood through an analysis of the natural environment. Therefore natural situations, not artificial situations such as experiments or formal interviews, must be a source of data. With a qualitative approach used in this study to describe or describe systematically, factually and accurately about the factors, traits and relationships between the phenomena 
under study and the resulting data in the form of words and images. The method used in researching the communication strategies of Islamic extension agents in the Indonesia-Malaysia border area is the case study method (Raco, 2018). And use the search for strengths, weaknesses, opportunities and threats to be able to find strategies in the communication of this mission (Septiadi, 2019).

\section{RESULT AND DISCUSSION}

The task of the Non-Civil Servant Islamic Religious Instructor is as a liaison that explains and describes something that may be considered new by the community as its target until the community is convinced and fully understands that what is considered new by them has more benefits for their lives.

The success of the communication activities of Non-PNS Islamic Extension Workers to the Paloh sub-district effectively is largely determined by the determination of communication strategies. Has been discussed in the previous literature review, that communication strategies can be said as a plan for an activity to change attitudes, traits, opinions, and behaviour of the audience (communicant, audience, or made), on a broad scale basis through the delivery of ideas or messages. The communication strategy used by the Non Civil Servant Islamic Religious Instructor in Paloh Subdistrict is to refer to the macro cognitive theory of Barbara $\mathrm{O}$ 'Keefe, which is based on the choice of strategy and message design.

\section{Selected Strategies of Non-PNS Islamic Extension Workers in Paloh District}

The choice of strategy in this research is a method used by Non Civil Servant Islamic Religious Instructors to choose from various appropriate strategies to be used in the process of delivering da'wah messages in Islamic guidance and counselling activities. The strategy used is based on the consideration of adjustments to the shape of the target audience. Customizing the preaching messages delivered is so that the message delivered can be right on target and can be understood by the audience or community who receive the message. The fostered forms of Non Civil Servant Islamic Religious Instructor in Paloh Subdistrict are divided into three namely, Al-Quran Education Park (TPQ), Mosque Youth and Taklim Assembly.

\section{Al-Quran Education Park (TPQ)}

How to deliver messages in the activities of Islamic guidance and counselling in the TPQ activities above, it appears that there are two methods used. The difference in the use of these methods is based on the different forms of TPQ activities themselves. There are TPQs held in mosques or surau, and there are also TPQs held at the home of the instructor itself. In general, the process of guidance and counselling of Islam in delivering da'wah messages to TPQ activities in the mosque uses how to read and memorize. Whereas TPQ activities carried out at home were conveyed only by reading.

\section{Teenage Mosque}

The messages given by the non-civil servant Islamic Religion instructor in Paloh Subdistrict to the adolescent fostered by the mosque are very simple. Although there is already a form of management that is found in adolescent mosques, the activities carried out are still not maximized. The activities have not been neatly organized, and still need deeper guidance. The process of delivering da'wah messages in the activities of adolescent mosques is carried out by reading, namely the reading of the Koran together and reading the Surah Yasin together. At each meeting only filled with reciting together. 
IJIK, Vol. 9 No. 2: 80-84

Communication Strategy Of Islamic Extension In The Indonesian-Malaysia Border Region

Halim Setiawan

\section{Taklim Assembly}

Based on the explanation above, it can be seen that the way of delivering the da'wah messages in the activities of Combigan and Islamic counselling to majelis taklim is carried out by lecturing and reading. This method is used because the form of the activities of the majelis taklim itself is different. When the Taklim Council is held in the form of study, the delivery of the messages using the lecture method. Whereas the majlis held in the form of recitation, then the delivery of messages carried out by reading.

\section{Message Design of Non-PNS Islamic Religious Instructor}

Da'wah messages delivered by Non Civil Servant Islamic Religious Instructors in Paloh Subdistrict can be grouped into two models of message preparation that are informative and persuasive. As made by Cassandra L. Book, she explained that there are two models in the preparation of messages, namely the preparation of messages that are informative and persuasive.

\section{Informative Messaging}

Preparation of messages that are informational in conveying propaganda messages on Islamic guidance and counselling activities made by Non-Civil Servant Islamic Religious Instructors in Paloh District is directed to three fostered forms namely the Al-Quran Education Park (TPQ), Mosque Ramaja Development, and Taklim Assembly.

1. Al-Quran Education Park (TPQ), The type of massage given by the Non-Civil Servant Islamic Religious Instructor of Paloh District in Islamic guidance and counselling activities in the TPQ activities is in the form of aqidah, worship and morals messages.

2. Mosque Youth, The type of message delivered to mosque youth is a message of worship and morals.

3. Taklim Council, Based on the level of the activities of the taklim assembly, the message of preaching delivered can be classified into two types of messages, namely the message of worship and the message of morals.

\section{Compilation of Persuasive Messages}

The compilation of messages that are persuasive carried out by Non Civil Servant Islamic Religious Instructors in the District of Paloh is to change and influence the attitudes and behaviour of the people of Paloh District. Da'wah messages delivered in Islamic guidance and counselling activities that use a persuasive message model are at the majelis taklim activities (Zuraidah, 2017). The message was compiled based on community needs and problems that are often faced by the community. The preparation is based on the type of message made, namely the message of worship and morals.

\section{CONCLUSION}

The choice of a strategy used by Non Civil Servant Islamic Religious Instructors in Paloh Subdistrict is based on the form of extension activities, both the Al-Quran Education Park (TPQ), Mosque Youth, and the Taklim Council. The strategy chosen to convey the messages of da'wah is to use how to read, memorize and lecture. The message design compiled by Non-Civil Servant Islamic Religious Instructors in Paloh Sub-district in the activities of the Al-Quran Education Park (TPQ), Mosque Youth, and Taklim Assembly was grouped into two models namely informative and persuasive messages with types of aqidah, worship and moral messages. 


\section{REFERENCES}

A'ing, A. (2015). Studi Tentang Pembangunan Bidang Pendidikan Di Daerah Perbatasan Kecamatan Kayan Hulu Kabupaten Malinau. EJournal Pemerintahan Integratif, 3.

Anisa, A. (2010). Aplikasi Paradigma Naturalistik Fenomenologi Dalam Penelitian Arsitektur. NALARs, 9(1).

Arifin, S. (2011). Migrasi Penduduk dan Implikasinya Terhadap Hankam di Wilayah Perbatasan Kalbar-Serawak, Malaysia. Masalah-Masalah Hukum, 40(2), 220-227.

Fauzi, A. (2019). Pengaruh Kompetensi terhadap Kinerja Pegawai pada Biro Pemerintahan dan Kerjasama Sekretariat Daerah Provinsi Jawa Barat. Politicon: Jurnal Ilmu Politik, 1(1), 87101.

Mayona, E. L., Salahudin, S., \& Kusmastuti, R. (2016). Penyusunan Arahan Strategi dan Prioritas Pengembangan Perbatasan Antar Negara di Provinsi Kalimantan Barat. TATALOKA, 13(2), 119-134.

Pasmika, A. D. T., \& Mauluddin, S. (2016). Sistem Informasi Kegiatan Penyuluhan Agama Di Kantor Urusan Agama Kecamatan Coblong Kota Bandung. Jurnal Manajemen Informatika (Jamika), $6(2)$.

Raco, J. (2018). Metode penelitian kualitatif: jenis, karakteristik dan keunggulannya.

Septiadi, M. A. (2019). Strategi Kualitas Pelayanan pada Dinas Kependudukan dan Catatan Sipil Kota Bandung. Politicon: Jurnal Ilmu Politik, 1(1), 71-86.

Sudarsana, I. K. (2016). Peningkatan mutu pendidikan luar sekolah dalam upayapembangunan sumber daya manusia. Jurnal Penjaminan Mutu, 1(1), 1-14.

Suradi, A. (2017). Globalisasi Dan Respon Pendidikan Agama Islam Di Sekolah. Jurnal MUDARRISUNA: Media Kajian Pendidikan Agama Islam, 7(2), 247-266.

Zuraidah, R. (2017). Pola komunikasi persuasif dalam fanspage Setia Furqon Kholid. IAIN Ponorogo. 